\title{
Small and Medium Business: Current Status and Sources of its Innovative Funding
}

\author{
M.A. Feyzullaev ${ }^{1}$, D.K. Shykhveledova ${ }^{1}, E . V$. Dolgov $^{1}$, and R.J. Javadov ${ }^{2}$ \\ ${ }^{1}$ Surgut State University, 628403 Surgut, Russia \\ ${ }^{2}$ Azerbaijan State University of Economics, 1001 Bak1, Azerbaijan
}

\begin{abstract}
The article analyzes the current development status of small and medium businesses in Russia. The authors reveal the dynamics of changes in the structure of investments in the Russian economy, where the share of small and medium businesses is especially noted. The direction of the trend and the expected trend of national entrepreneurial activity in the country are determined. The role of state support for small business development is assessed and the main directions in this area are determined. The main sources of financing for small and medium businesses are analyzed. The role of lending in this sector of the economy is noted; issues, risks, and prospects for the use of innovative methods of small business funding are identified. The analysis of the activity of participation of small businesses in the market of debt securities is carried out. In particular, the dynamics of the volume of placement of bonded loans of the small business sector is analyzed, the possibilities of entering the equity capital market through an IPO are being studied. Another innovative area of small and medium business funding is the venture capital financing, which is the most attractive for new startups. The authors revealed a fourfold increase in this type of financing over the past four years. In addition, the article also provides an assessment of alternative sources for small and medium business funding.
\end{abstract}

\section{Introduction}

One of the strategic goals of the development of the Russian economy within the framework of the national project "Small and Medium Enterprises and Support of Individual Entrepreneurial Initiatives" is to ensure the accelerated development of medium and small business, to achieve a gradual increase in its share in non-primary exports to $10 \%$, and in the total GDP of the Russian Federation to $32.5 \%$ by 2024 [1]. At the same time, a different trend is currently observed - the share of this segment in the domestic economy decreased at the end of 2018 from $22 \%$ to $20.2 \%$, and the number of small and medium-sized entrepreneurship entities as of early October 2020 decreased by 222 thousand compared to the same period last year [2].

Discussions of economists, specialists and business representatives again are boiled down to identifying the key issues preventing the formation of more national favorable conditions for doing business, providing the necessary access to a wide range of external financing sources. 


\section{Materials and methods}

The scientific works of such economists and scientists as S.P. Zemtsov, Yu.V. Tsareva, E.M. Bukhvald, S.V. Terebova, S.V Schurina are devoted to the issue of assessing the current state of the small and medium-sized business sector and the study of its development trends. $[3,4,5,6]$.

The peculiarities of using traditional sources of capital attraction in Russia by small and medium businesses are considered in the studies of N.E. Yegorova, E.A. Koroleva, L.S. Shavaleeva [7.8]. In turn, A.E. Ushanov, E.V. Chernikina, V.M. Utyeva, V.A. Tegin, B.F. Usmanov, S.Yu. Salomatina pay special attention to innovative forms of financing the activities of enterprises and assessing the practice of their use in Russia [9,10,11,12].

During the research work, the methods of theoretical, statistical and comparative analysis, synthesis, integrated approach, scientific abstraction and generalization were used.

\section{Results and discussion}

It is well known that capital is the basis for establishing an enterprise, conducting financial and economic activities in the market economy, a source of assets and covering the organization's liabilities, ensuring its continuous functioning and profit maximization. In the economic literature, equity capital is traditionally distinguished, which is understood as all own sources of financing the organization's activities, created and additionally accumulated to ensure the further functioning of the enterprise, and the borrowed capital. It should be noted that in the works of modern economists there are different interpretations of the essence of borrowed capital, which is also identified with the concepts of "capital raised" and "loan capital".

According to T.A. Yakovets, in order to define the structural part of the enterprise capital, the concept of "loan capital" should be used, since the word "loan", from which it is derived, in contrast to the "credit", is more meaningful and involves the transfer of funds and other values for use [13]. According to the study of Yu.I. Bakhturina, the loan capital is a part of the attracted capital of the enterprise and means a set of sources of funds of the organization that they received "in cash or in kind from organizations, individuals, the state on terms of return and for a certain fee through a voluntary agreement of the parties in order to obtain economic profit (benefits) as a result of their productive use". [14].

Table 1. Capital Investment Pattern in the Russian Federation. During the period from $2014-1^{\text {st }}$ half of 2020.

\begin{tabular}{|l|r|r|r|r|r|r|r|r|}
\hline \multicolumn{1}{|c|}{ Indicator } & \multicolumn{1}{|c|}{2014} & 2015 & 2016 & 2017 & 2018 & 2019 & $\begin{array}{c}\text { I half } \\
\text { of 2020 }\end{array}$ \\
\hline Capital Investments - total, \% & $\mathbf{1 0 0 . 0 0}$ & $\mathbf{1 0 0 . 0 0}$ & $\mathbf{1 0 0 . 0 0}$ & $\mathbf{1 0 0 . 0 0}$ & $\mathbf{1 0 0 . 0 0}$ & $\mathbf{1 0 0 . 0 0}$ & $\mathbf{1 0 0 . 0 0}$ \\
\hline \multicolumn{2}{|l|}{ Including by funding sources: } \\
\hline Internal funds & 45.7 & 50.2 & 51.0 & 51.3 & 53.1 & 57.1 & 60.9 \\
\hline Attracted funds & 54.3 & 49.8 & 49.0 & 48.7 & 46.9 & 42.9 & 39.1 \\
\hline where: & & & & & & & \\
\hline Bank credits funds of other & 10.6 & 8.1 & 10.4 & 11.2 & 11.2 & 8.7 & 9.8 \\
\hline $\begin{array}{l}\text { Borrowed } \\
\text { organizations }\end{array}$ & 6.4 & 6.7 & 6.0 & 5.4 & 4.3 & 4.5 & 5.5 \\
\hline Foreign investments & 0.9 & 1.1 & 0.8 & 0.8 & 0.6 & 0.5 & 0.4 \\
\hline Budgetary funds & 17.0 & 18.3 & 16.4 & 16.3 & 15.3 & 15.8 & 12.8 \\
\hline State non-budgetary funds, etc. & 19.4 & 15.6 & 15.4 & 15.0 & 15.5 & 13.4 & 16.2 \\
\hline
\end{tabular}

Note: drafted by authors according to [15].

Based on the Rosstat data, with the onset of the economic and currency crisis in Russia in 2014, the structure of the aggregate capital of Russian enterprises has undergone significant changes. If earlier the share of borrowed capital exceeded $50 \%$, then after 6 
years, equity capital became the key source of financing for domestic companies; by June 2020, the share of equity capital increased by 15.2 percentage points compared to 2014 . This phenomenon can be considered quite natural amid the crisis in financial markets, limited opportunities for foreign investment attraction in connection with the sanctions' rhetoric of the international community against Russia, increased competition, when the priority for management is to ensure the financial stability and solvency of the company in the long term, as well as opportunities implementation of control over its activities, regardless of external factors.

Due to restrictive measures introduced by state authorities in March 2020 aimed at preventing an increase in the incidence of diseases, the activities of a huge number of small and medium-sized enterprises operating in wholesale and retail trade, tourism, construction, health care, in the field of culture, sports, organization of entertainment events, etc. were completely suspended for several months. In combination with another fall in the ruble exchange rate, a decrease in consumer demand and the level of real disposable income of the population, the lack of opportunities for more than 21.6 thousand small and mediumsized businesses to receive state funding, this resulted in the closure of 222 thousand companies during the year as of 10.10.2020 compared to the same period last year (Fig. 1).

One of the key agendas in this situation was the issue of expanding the already existing measures of state support for small and medium businesses, which are being implemented in order to achieve structural restructuring of the sector according to an innovative type and high-quality development of the domestic economy.

In April 2020, the state began implementing additional measures to support small and medium enterprises most affected by the pandemic, which include:

- allocation of budgetary funds to credit institutions to ensure the deferral of payments on loans issued to small and medium businesses;

- provision of loans for the payment of wages to employees of enterprises on preferential terms and the possibility of deferring rental payments when the federal property is leased;

- the introduction of a moratorium on the initiation of bankruptcy cases on applications of creditors and on conducting inspections in relation to small businesses (with the exception of tax, customs and financial and budgetary control);

- creating conditions for providing preferential access for small and medium-sized businesses to the infrastructure of industrial parks and technical parks;

- encouraging entrepreneurs to participate in export activities and the creation of the institute of "bona fide exporter" in order to improve the business climate in the country;

- subsidizing of measures preventing the spread of coronavirus infection;

- provision of a 6-month deferral (installment plan) for all taxes (excluding VAT), and for micro-enterprises, including insurance contributions to extra-budgetary funds, with the simultaneous introduction of a moratorium on collection of debts and fines $[17,18]$. 


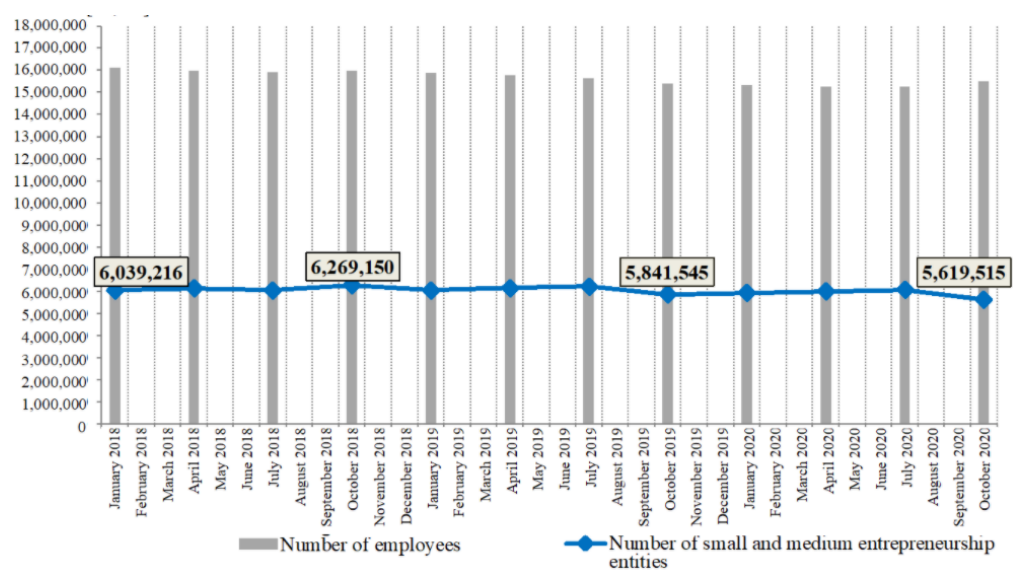

Fig. 1. Dynamics of small and medium entrepreneurship entities' quantity for the period from 10.01.2018 to 10.10 .2020

Note: drafted by authors according to [16].

However, the resources of the state are quite limited, therefore, only those small and medium businesses meeting the requirements established in regulatory legal acts are eligible to participate in the above-mentioned programs of financial support. According to the survey conducted in April 2020 by the Chamber of Commerce and Industry of the Russian Federation, at that time, measures of state support were unavailable for $48 \%$ of domestic entrepreneurs operating in sectors of the economy that were not included in the register defined by the Resolution of the Government of the Russian Federation dd. 03.04.2020 No. 434 "On approval of the list of Russian economy sectors most seriously affected amid the deteriorating environment in the result of novel coronavirus infection spread" $[19,20]$. As a result, the crisis economic situation and the lack of own funds for the further implementation of activities actualizes the problem of attracting external financing and choosing the most effective instrument for existing and emergent entrepreneurs.

As mentioned earlier, one of the key objectives of Russia's modern policy to support small and medium businesses is to expand their access to financial resources, including credit, which is achieved through various measures. So, according to "Expert RA" data, in 2019 the volume of lending to small and medium businesses reached the record value over the past six years: 7.8 trillion. RUB (Fig. 2). This is largely associated with the functioning of state support programs, with the decrease in the key interest rate of the Central Bank of the Russian Federation throughout 2019, which subsequently led to a gradual fall in the weighted average interest rate on bank loans to small and medium businesses, as well as increased competition between domestic banks for new high-quality borrowers [21].

However, according to A.E. Ushanov, only every tenth small or medium-sized enterprises in Russia can count on approval of a loan, since the main segment of clients for banks remains large companies, which, as a rule, request more significant amounts, have greater financial stability, and whose lending is not so strictly regulated with parties of the Bank of Russia [9]. As a result, many entrepreneurs receive loans as individuals, or take-out loans from dubious lenders - both options are rather risky and sub-optimal.

The current the bank lending market situation for to small and medium-sized businesses makes another source of financing for their activities more attractive - leasing. In general, the use of leasing as a funding instrument is effective only for those small and mediumsized enterprises that need fixed capital to modernize or expand production. If the company needs money for further activities, then another direction of attracting borrowed capital 
should be considered: the use of such stock market instruments as the issue of bonds and shares.

The right to issue debt and equity securities allows small and medium-sized enterprises to attract large amounts of investment to finance and expand production activities, especially in the context of the developing bond market in Russia and active government support. In order to simplify access to stock market instruments for small and mediumsized businesses, the Government of the Russian Federation has taken the following steps within the framework of the project "Expanding access of SMEs to financial resources, including concessional financing":

- Subsidized the listing of shares and bonds, which implies compensation of the enterprise's expenses for the placement of securities up to $2 \%$ of the issue amount (up to 1.5 million rubles), as well as compensation of up to $70 \%$ of the volume of coupon payments on bonds [22];

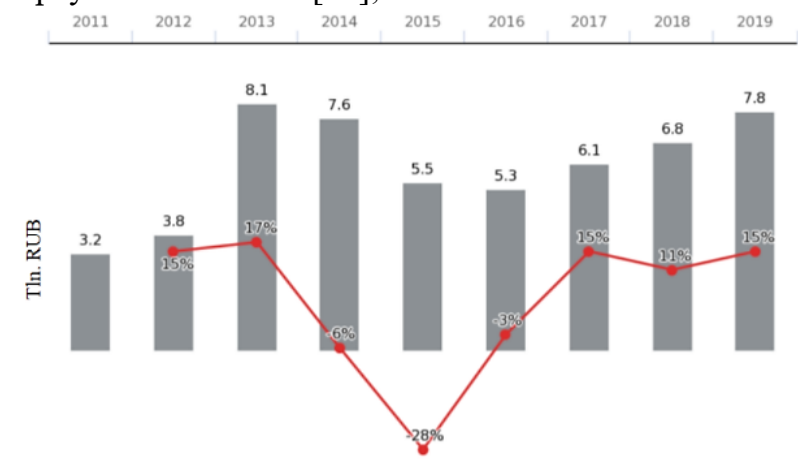

- Annual loan volume to small and medium entrepreneurship entities

- Annual growth rate of loan volume to small and medium entrepreneurship entities

Fig. 2. Loan volume to small and medium entrepreneurship entities during 2011-2019 [25]

- with the support of the Industrial Development Fund, the Russian Direct Investment Fund, the SME Corporation and the Russian Export Center, on July 24, 2017, the Moscow Exchange created a special exchange segment, the Growth Sector, which key task is to "promote investment attraction by small and mediumsized companies", necessarily corresponding to a number of requirements for the volume of proceeds and the period of existence (see Fig. 3) [23];

- surety and guarantee support of the SME Corporation small and medium entrepreneurship entities in the issue of bonds;

- MSP Bank together with Russian credit institutions for the period 2019-2020 placed securitized bonds, secured by a portfolio of loans to small and medium businesses for the amount of more than 20 billion rubles for the purpose of subsequent preferential lending to entrepreneurs at the expense of attracted funds [23].

According to data of the Ministry of Economic Development of the Russian Federation, in 2019, following the results of two stages of accepting applications, were selected 7 small and medium businesses, which were collectively compensated for the costs of placing bonds in the "Growth Sector" and payment of coupon income in the amount of 6.6 million rubles and 5 million rubles, respectively. As a result, these companies managed to attract about 3.1 billion rubles through the issue of bonds in order to finance their activities [23]. 


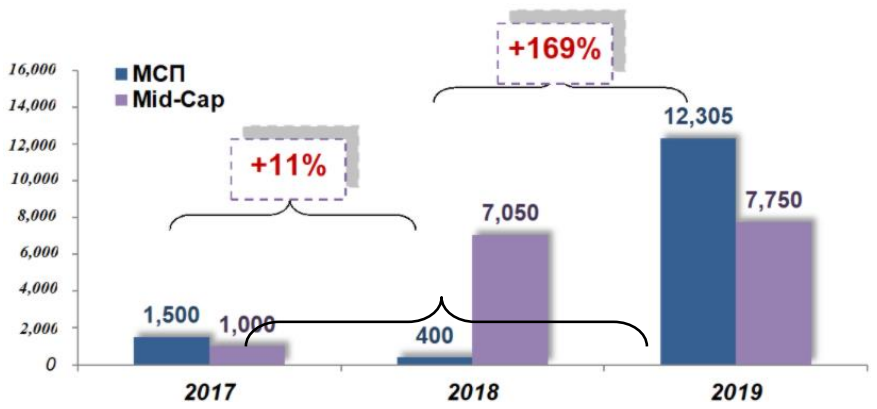

Fig. 3. Size of bond offering of small and medium entrepreneurship entity and Mid-Cap in the Growth Sector for 2017-2019, in mln. RUB

Note: drafted by authors according to [24].

Further are defined the peculiarities of venture financing, a relatively new source of capital raising for Russian business compared to the previously considered instruments, the spread of which began in the late 1990s.

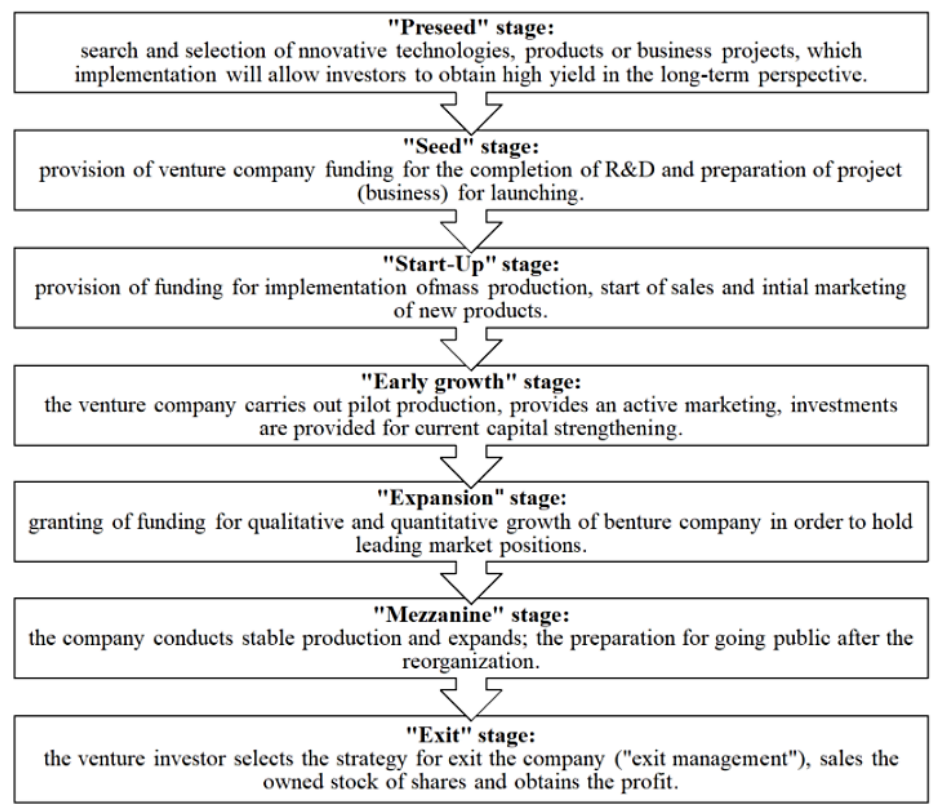

Fig. 4. Venture investment stages.

Note: drafted by authors.

Under the venture financing is understood as long-term and high-risk capital investments of private investors (business angels), large enterprises and venture capital funds in primarily innovative companies that are at the stage of formation and at the same time have significant potential for further growth. A detailed description of the key stages of venture financing is presented in Fig. 4.

According to A.F. Glisin and A.S. Paluvina, the venture financing has a number of distinctive advantages that make this tool more and more attractive for start-up entrepreneurs who want to bring an innovative product to the market: 
1) The venture company is provided with significant financial support for a long period of formation, which allows it to further reach the level of maturity and use other sources of capital raising;

2) From the very beginning of the project implementation, the enterprise has no obligation to pay interest on the capital provided by venture investors or to fully reimburse it;

3) Venture companies have the opportunity to learn from business angels and venture funds the experience in the field of financial management and business relations, to take advantage of technological developments provided by them, legal and consulting support;

4) Venture financing is one of the most effective ways to accelerate the commercialization of innovative products, their real promotion in the market [25].

At the same time, the main disadvantages of venture financing, in addition to the high risk of investments, include the likelihood of losing control over the company in the future as a result of the redistribution of ownership, the requirement for a high rate of return on the part of venture capitalists and the absence of an established market segment for the sale of an innovative and high-tech product.

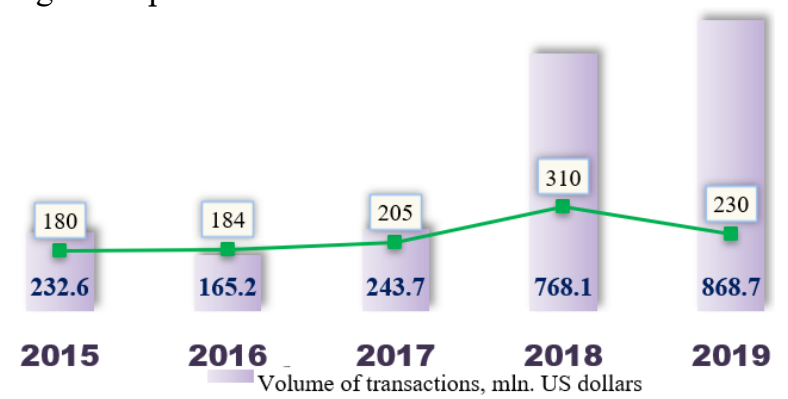

Fig. 5. Dynamics of Russian venture market for 2015-2019. (without considering exit transactions).

Note: drafted by authors according to [26].

According to analysts of "Dsight" BI platform, 230 transactions were concluded in the Russian venture capital market in 2019 , which is $26 \%$ less than in 2018 . However, the total volume of investments in projects at various stages within the framework of these transactions amounted to a record $\$ 868.7$ million, an increase of $13 \%$ over the year, resulting in the natural increase in the average transaction amount - from $\$ 1.5$ million up to $\$ 3.1$ million. In addition, by the end of 2019 , the volume of exits from venture companies, mainly operating in Russia, increased many times - from 349.7 million US dollars in 2018 to 5555.7 million US dollars, which allowed the domestic venture capital market to enter the TOP-10 venture economies of the world [26].

In general, the development of the venture capital ecosystem in Russia is characterized by the following trends:

- After the rapid growth of the venture capital market in the 2010's and a sharp decline in the volume of investments due to the economic crisis in 2014, the gradual stabilization is observed;

- the number of business angels increases, and their contribution to the development of the venture capital market becomes more significant;

- in the total volume of investments, the share of large corporations increases which continue to increase investments in startups and projects at the stage of expansion, as well as actively develop their own accelerators and venture funds to search for innovative solutions; 
- the main direction of venture investments is information and communication technologies, while "deeptech startups" are becoming more and more promising, focused on engineering and technological advances in the field of machine learning, 5G networks, the Internet of things, industrial security, medicine and cybersecurity;

- business angels, state venture funds and accelerators remain the main support for startups that are mainly focused on the local market or offer complex technological products;

- the uneven distribution of venture capital investments across regions remains: more than half of their total volume falls on the Central Federal District;

- there is a sharp decrease in investments of foreign investors in 2019 against the background of the negative business climate in Russia and a slowdown in the growth of the domestic economy;

- There is a transformation of the IIDF strategy: the key state institution in the domestic venture capital market, which plans to further provide financial support mainly to foreign startups with Russian roots and start-up companies planning to enter the international market [10,26, 27].

Let's move on to considering the previously identified alternative ways of attracting financing to small and medium-sized enterprises and highlight their features (Table 3 )

Table 3. Innovative forms of small and medium enterprise activity funding

\begin{tabular}{|c|c|c|}
\hline Capital instrument & Advantages & Disadvantages \\
\hline $\begin{array}{l}\text { Crowdfunding means } \\
\text { "a collective } \\
\text { collaboration of } \\
\text { people who pool } \\
\text { their resources, } \\
\text { usually via the } \\
\text { Internet, to support } \\
\text { the efforts of other } \\
\text { people or } \\
\text { organizations" [11]; } \\
\text { the funding method } \\
\text { based on voluntary } \\
\text { donations from } \\
\text { sponsors (backers) or } \\
\text { donation of funds in } \\
\text { exchange for } \\
\text { intangible } \\
\text { remuneration. }\end{array}$ & $\begin{array}{l}\text { - placement of the company's } \\
\text { project on a crowdfunding } \\
\text { platform allows to determine in } \\
\text { advance the level of demand for } \\
\text { the proposed product from a } \\
\text { potential consumer, assess the } \\
\text { feasibility of the project itself for } \\
\text { its production and hedge risks; } \\
\text { a crowdfunding platform is an } \\
\text { effective marketing tool, since, as } \\
\text { a rule, it provides a company } \\
\text { with the opportunity to advertise } \\
\text { its project in unlimited volumes, } \\
\text { and also allows the manufacturer } \\
\text { to actively communicate with a } \\
\text { potential consumer [11]; } \\
\text { there is no risk of loss of control } \\
\text { over the company and } \\
\text { participation of third parties in } \\
\text { the management of business } \\
\text { processes; } \\
\text { convenience, transparency and } \\
\text { flexibility of crowdfunding } \\
\text { platforms in terms of information } \\
\text { about the project and } \\
\text { organization of fundraising; } \\
\text { obtaining of government support. }\end{array}$ & 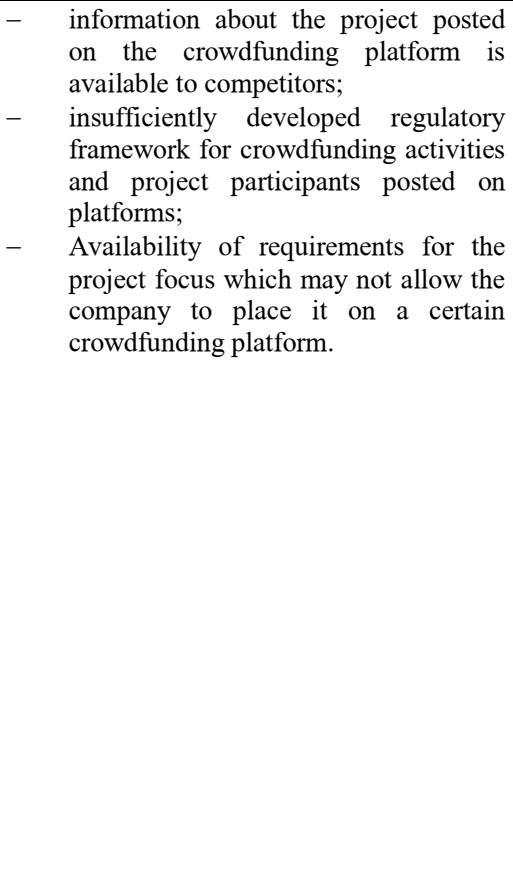 \\
\hline
\end{tabular}


Table 3. Continued

\begin{tabular}{|c|c|c|}
\hline $\begin{array}{l}\text { Franchising means a } \\
\text { type of } \\
\text { entrepreneurial } \\
\text { activity that involves } \\
\text { building a mutually } \\
\text { beneficial } \\
\text { relationship between } \\
\text { the franchisor and } \\
\text { the franchisee subject } \\
\text { to payment (royalty) } \\
\text { for transferring the } \\
\text { right to carry out a } \\
\text { certain type of } \\
\text { business based on a } \\
\text { business model } \\
\text { developed by the } \\
\text { franchisor. }\end{array}$ & $\begin{array}{l}\text { for franchisees, i.e., companies } \\
\text { that are at the initial stage of } \\
\text { formation and are trying to } \\
\text { establish themselves in a certain } \\
\text { area of business; franchising is a } \\
\text { tool to minimize entrepreneurial } \\
\text { risks and reduce costs for } \\
\text { developing an effective business } \\
\text { model, marketing, purchasing } \\
\text { equipment, inventory, etc., } \\
\text { including due to the support of } \\
\text { the franchisor; } \\
\text { for a franchisor who intends to } \\
\text { sell a franchise to other } \\
\text { entrepreneurs for doing business, } \\
\text { this is a source of additional } \\
\text { income (through royalties), an } \\
\text { opportunity to gain a large } \\
\text { market share without significant } \\
\text { investments in infrastructure } \\
\text { development and advertising } \\
\text { costs; } \\
\text { each party to the commercial } \\
\text { concession (franchise) agreement } \\
\text { retains its legal independence } \\
\text { obtaining of government support. }\end{array}$ & $\begin{array}{l}\text { - for franchisees: the presence of } \\
\text { restrictions in actions and lack of } \\
\text { flexibility within the framework of the } \\
\text { contract, the constant control by the } \\
\text { franchisor, the need to adapt the } \\
\text { business model to the peculiarities of } \\
\text { the local market, obligations to pay } \\
\text { royalties to the franchisor, lack of full } \\
\text { and reliable information about } \\
\text { franchises; } \\
\text { a lack of a full-fledged regulatory } \\
\text { framework for regulating relations } \\
\text { formed within the framework of } \\
\text { franchising; } \\
\text { for the franchisor: the presence of risks } \\
\text { associated with the likelihood of loss } \\
\text { of reputation due to the failure of the } \\
\text { franchisee to comply with the relevant } \\
\text { instructions and standards of activity, } \\
\text { failure to pay royalties, providing the } \\
\text { franchisee with inaccurate information } \\
\text { about the specifics of the local market; } \\
\text { the need to take measures to preserve the } \\
\text { confidentiality of trade secrets. }\end{array}$ \\
\hline $\begin{array}{l}\text { Asset securitisation } \\
\text { means a a } \\
\text { mechanism for } \\
\text { attracting financing } \\
\text { by a company, which } \\
\text { involves the } \\
\text { transformation of } \\
\text { low-liquid assets into } \\
\text { liquid assets by } \\
\text { issuing securities } \\
\text { (usually bonds) } \\
\text { backed by certain } \\
\text { assets that generate } \\
\text { stable positive cash } \\
\text { flows. }\end{array}$ & 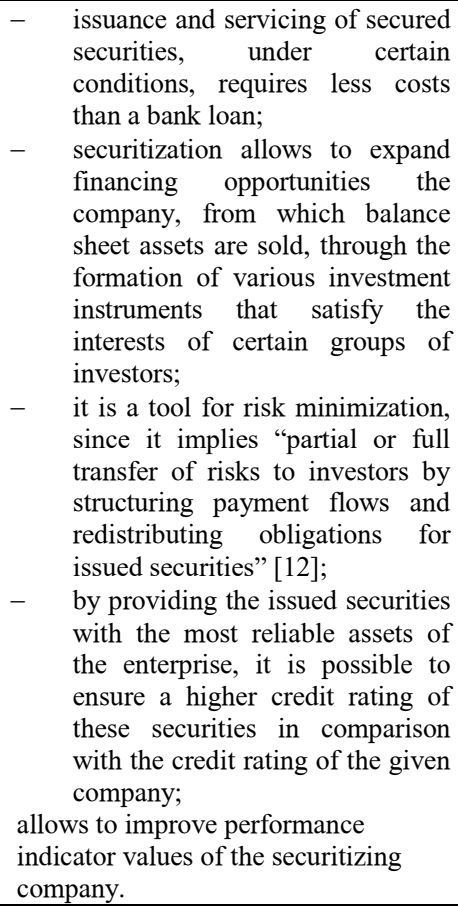 & 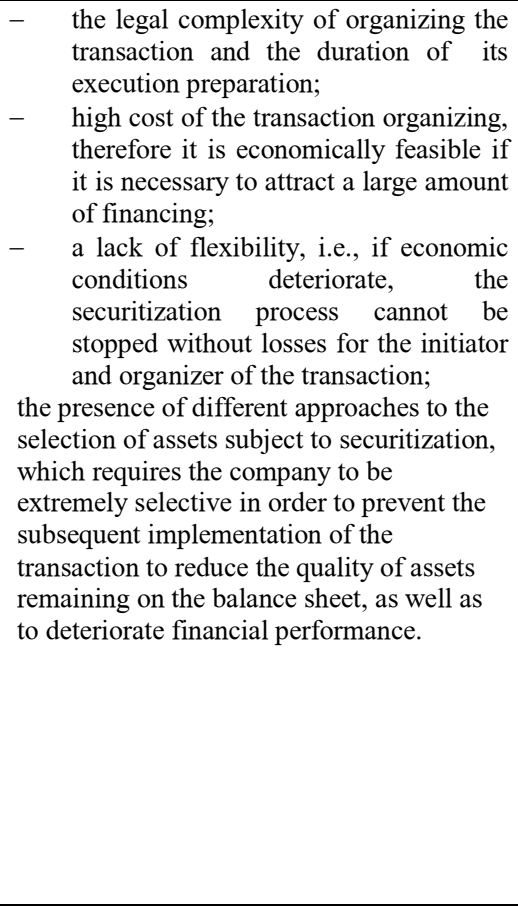 \\
\hline
\end{tabular}

It should be noted that with the spread of the practice of collective financing of various projects by private investors, two more instruments have emerged that are slightly different from crowdfunding:

1) The crowdinvesting is financing the activities of small and medium-sized businesses, as well as individual entrepreneurs, either by purchasing an investor's share in 
the company's share capital, or by purchasing royalties, i.e., the share of the future profit of the financed project;

2) The crowdfunding is a form of financing that involves the provision of a loan (loan) for the implementation of a project of an individual (P2P lending) or legal entity (P2B lending).

\section{Conclusion}

The role of small and medium businesses in post-industrial countries with the developed economy is great, since enterprises in this business segment, as a rule, are the driver of economic growth and the main source of tax revenues to the budget, are interested in the development and implementation of innovative technologies in production activities, provide the creation of a significant number of new jobs and an increasing the size of the middle class. This is the reason that one of the present key directions of state economic policy in Russia is the support small and medium businesses.

However, unlike large corporations, small and medium enterprises constantly face the problem of insufficient own financial resources for further implementation of current activities and business expansion, which leads to the active use of traditional mechanisms for attracting additional capital and the emergence of innovative forms of financing. Based on the results of the feature comparative analysis, it can be concluded that the most effective method of attracting funding is the optimal combination of various instruments.

For a competent choice of sources of financing, a company must first analyze its own capabilities, determine the real number of financial resources required for the successful implementation of a project or the implementation of further activities of the enterprise, understand the features of the market to which the product is oriented, and then, based on the results obtained, highlight the advantages and disadvantages of each mechanism for attracting funding.

\section{References}

1. National project «Small and Medium-Sized Businesses and Support of Individual Entrepreneurial Initiatives», Official website of Ministry of Economic Development of the Russian Federation, https://www.economy.gov.ru/

2. "RBC" News Agency: Rosstat recorded the decrease of small business share in economy, https://www.rbc.ru/

3. S.P. Zemtsov. Yu.V. Tsareva, Russian Economic Development, 5(27), 71 (2020)

4. E.M. Buchvald, Economic and social changes: facts, trends, forecast, 1(43), 66 (2016)

5. S.V. Terebova, Economic and social changes: facts, trends, forecast, 10(1), 178 (2017)

6. S.V. Schurina, Economics. Taxes. Law, 13(1), 60 (2020)

7. N.E. Egorova, E.A. Koroleva, Higher School of Economics Economic Journal, 2, 191 (2020)

8. L.S. Shavaleeva, Journal of Entrepreneurship, 4, 551 (2017)

9. A.E. Ushanov, ASTU Bulleting, series: Economics, 1, 117 (2020)

10.E.V. Chernikina, V.M. Utyeva, Theoretical and Applied Issues of Economics, Management and Education: Materials of International Research and Practice Conference, Penza, 220 (2020)

11. V.A. Tegin, B.F. Usmanov, World of Transport, 4(53), 98 (2014)

12. S.Yu. Salomatina, Koncept, 8, 116 (2014) 
13. T.A. Yakovets, International Accounting, 28(274), 35 (2013)

14. Yu.I. Bakhturina, VSU Bulletin: Economics and Management, 2, 92 (2006)

15. Capital Investment Pattern in the Russian Federation, Official website of Rosstat, https://rosstat.gov.ru/

16. Unified Register of Small and Medium-Sized Business Entities, Official website of Federal Tax Service of the Russian Federation, https://ofd.nalog.ru/

17. A.D. Levashenko, A.A. Koval, Economic Development of Russia, 5(27), 66 (2020)

18. List of instructions following the Extended Meeting of the Presidium of State Council dated September 28, 2020, Official website of the President of Russia, http://kremlin.ru/

19. «Rosbalt» News Agency: “Almost 50\% Russian small and medium enterprises couldn't obtain the support", https://www.rosbalt.ru/business

20. Resolution of the Government of the Russian Federation dd. 03.04.2020 No. 434 "On approval of the list of Russian economy sectors most seriously affected amid the deteriorating environment in the result of novel coronavirus infection spread"

21. "Expert RA" Rating Agency: "Forecast of small and medium business lending in Russia for 2020: records in the past", https://raexpert.ru/

22. Resolution of the Government of the Russian Federation dd. 30.04.2019 No. 532 "On approval of Rules for granting federal subsidies for Russian organizations: small and medium-sized entrepreneurship entities in order to compensate a share of expenses on issue of shares and bonds and payment of coupon yield for bonds listed on stack exchange"

23. "TASS" News Agency: "MSP Bank has fulfilled the size of business lending portfolio bond offering", https://tass.ru/

24. Moscow Exchange Growth Sector, Official website of Moscow Exchange, https://www.moex.com/

25. A.F. Glisin, A.S. Palyuvina, Economy Vector, 6(24), 28 (2018)

26. Venture Russia. Results for 2016-2019, Official website of Dsight, https://dsight.ru/

27. E.G. Sheina, Russian economic bulletin, 2, 206 (2020) 